\title{
Les minéralisations Cu---(Ni---Bi---U---Au---Ag) d'Ifri (district du Haut Seksaoua, Maroc) : apport de l'étude texturale au débat syngenèse versus épigenèse
}

\section{The Cu---(Ni---Bi---U---Au---Ag) mineralization of Ifri ('Haut Seksaoua' district, Morocco): contribution of a textural study to the discussion syngenetic versus epigenetic}

\author{
Luc Barbanson $^{a}$, Alain Chauvet ${ }^{a}$, Aziz Gaouzi ${ }^{b}$, Lakhifi Badra ${ }^{b}$, Mohamed Mechiche \\ Jean Claude Touray ${ }^{\mathrm{a}}$ and Saïd Oukarou ${ }^{\mathrm{c}}$ \\ ${ }^{\text {a }}$ Institut des sciences de la Terre d'Orléans (ISTO), université d'Orléans, bât. Géosciences, BP \\ 6759, 45067, Orléans cedex 2, France \\ ${ }^{\mathrm{b}}$ Département de géologie, université de Meknés, Meknés, Maroc \\ c Snarema, Casablanca, Maroc
}

\section{Résumé}

Les minéralisations à Cu d'Ifri se présentent sous la forme d'un stockwerk de chalcopyrite, encaissé dans des formations cambriennes. Elles ont jusqu'à présent été interprétées en terme d'amas sulfuré syngénétique. Nos travaux ont montré que le stockwerk à chalcopyrite est sécant sur une génération de pyrite postérieure à une déformation régionale. La présence dans la paragenèse du stockwerk d'une association $\mathrm{U}, \mathrm{W}, \mathrm{Sn}$ ainsi qu'une datation $\mathrm{Pb} / \mathrm{Pb}$ de brannérite, contemporaine de la minéralisation cuprifère, permet d'envisager le rôle du granite du Tichka dans la genèse du gîte d'Ifri. Pour citer cet article : L. Barbanson et al., C. $R$. Geoscience 335 (2003).

\section{Abstract}

The $\mathrm{Cu}$ ore of Ifri is a chalcopyrite stockwork hosted by Cambrian formations and was until now interpreted as a syngenetic massive sulphide deposit. Textural studies highlight two generations of pyrite early (Py I) and late (Py II) with respect to the regional deformation. The chalcopyrite stockwork overprinted Py II, outlining the epigenetic nature of the $\mathrm{Cu}$ mineralization. Regarding the origin of Cu-depositing fluids, the presence in the stockwork paragenesis of an $\mathrm{U}, \mathrm{W}, \mathrm{Sn}$ association and preliminary $\mathrm{Pb} / \mathrm{Pb}$ dating of a brannerite belonging to this association suggest a contribution of the Tichka granite.

Mots-clé: cuivre; pyrite; stockwerk; cisaillement; Tardi-Hercynien; Haut Atlas; MarocMotsclé: copper; pyrite; stockwork; shearing; Late Hercynian; High Atlas; Morocco 


\section{Abridged English version}

\section{Introduction}

The 'Haut Seksaoua' district is located to the west of the High Atlas Mountains (Morocco), at the western limit of the hornfels associated with the Late-Carboniferous Tichka granite (291 $\pm 5 \mathrm{Ma}$, [4 and 9]). It includes the Cu-mineralization of Ifri interpreted as a Volcanogenic Massive Sulphide Deposit [5 and 6]. Our mineralogical observations coupled with a preceding structural study [2] led us to question the former typological attribution.

\section{Geological setting}

The Ifri sequence comprises from bottom to top: lower carbonate-shale, black-shale, grey dolostone, upper carbonate-shale, pelites and sericiteous shale. These formations are considered as Cambrian in age [6].

The Ifri area suffered three stages of ductile deformations [2]. The first stage (D1) created a foliation (S1) transposing stratification (S0). The second stage (D2) resulted in the formation of knee-folds associated with NNW-ward thrusting and crenulating S1. The third stage (D3) was related to east-west shortening. These deformations are thought to be Hercynian in age [2]. The tectonic history ended with two stages of faulting.

\section{The Cu-bearing mineralization of Ifri}

Two types of sulphide mineralization have been observed at Ifri: a massive pyrite mineralization and a chalcopyrite stockwork overprinting grey dolostone, black shales, massive pyrite mineralization and lower carbonate shales. This stockwork is well developed in 100 m-sized stratabound lens-shaped breccia with a coarse-grain white dolomite matrix. This 'white dolomite breccia' underlies black shales and grades both laterally and at the footwall into the lower carbonate shales (Fig. 1). The 'white dolomite breccia' is the favourite host of the Cu stockwork, it will be described in the following section.

\subsection{Pyrite mineralization}

According to textural features, two types of pyrites may be distinguished: disseminated (Fig. 2a) in black shales and massive at the hanging-wall and footwall of the black-shale unit. Massive pyrite mineralization consists in a monomineralic cluster of pyrite crystals (Py I) displaying a rough cleavage (Fig. 2b). Joints between $\mathrm{FeS}_{2}$ grains show annealing texture. Bands exhibiting collomorphic texture (Fig. 2c) appear occasionally within the massive pyrite mineralization. These 'melnikovite' ribbons parallel the stratification of the host rock. The transition between collomorphic texture and annealing texture is marked by gradual fading of the former into the latter. Nitric acid etching does not reveal any structure in disseminated or massive Py I grains. The textural features of massive (and disseminated) pyritic mineralization are characteristic of metamorphosed pyritic ores (e.g., [1, 7 and 8]). Collomorphic pyrite bands can be considered as relics of a pre-metamorphism mineralization (Py 0). 


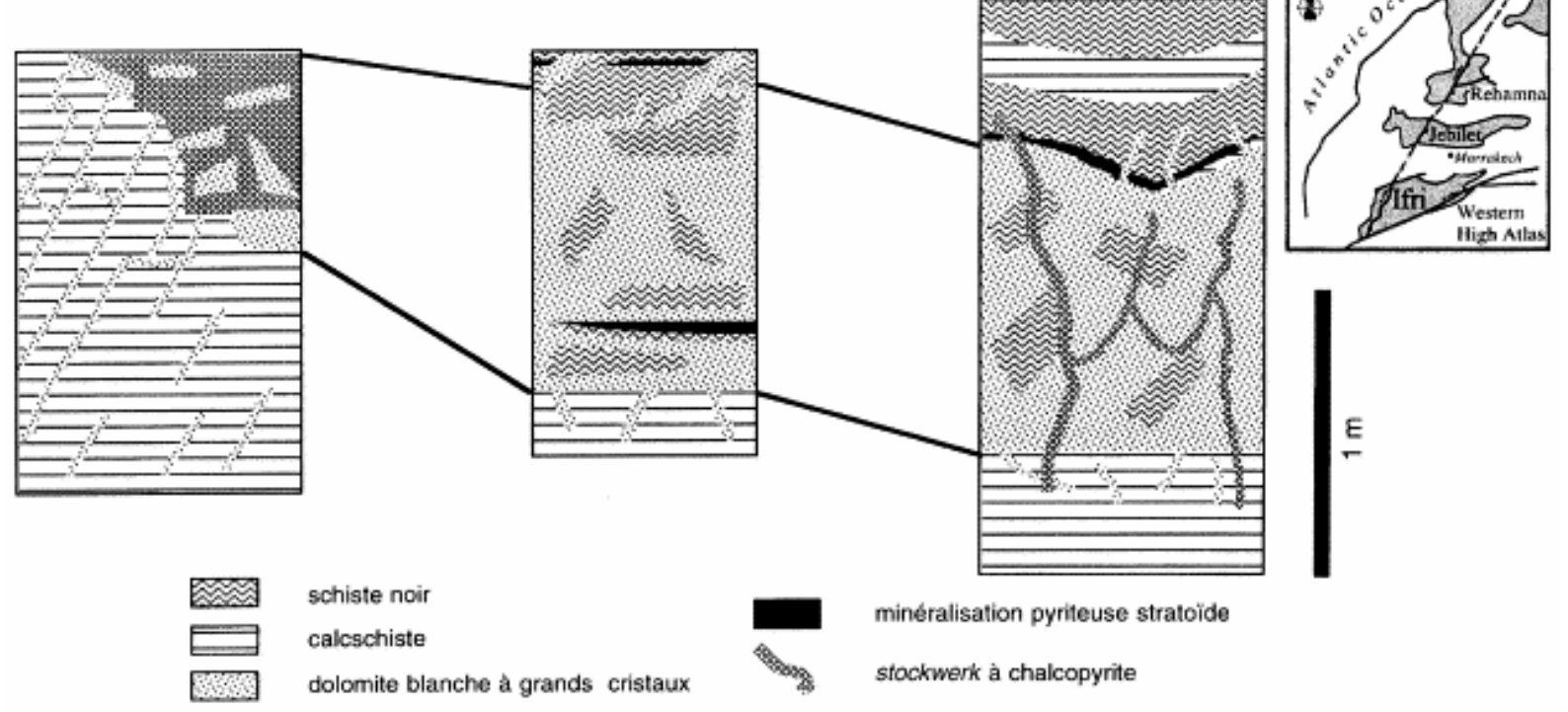

Fig. 1. Relations entre minéralisation pyriteuse massive, dolomie blanche à grands cristaux et stockwerk cuprifère (niveau 1 de la mine d'Ifri).Relationship between massive pyritic mineralization, coarse-grained white dolomite and $\mathrm{Cu}$ stockwork (level 1 of the Ifri mine). 

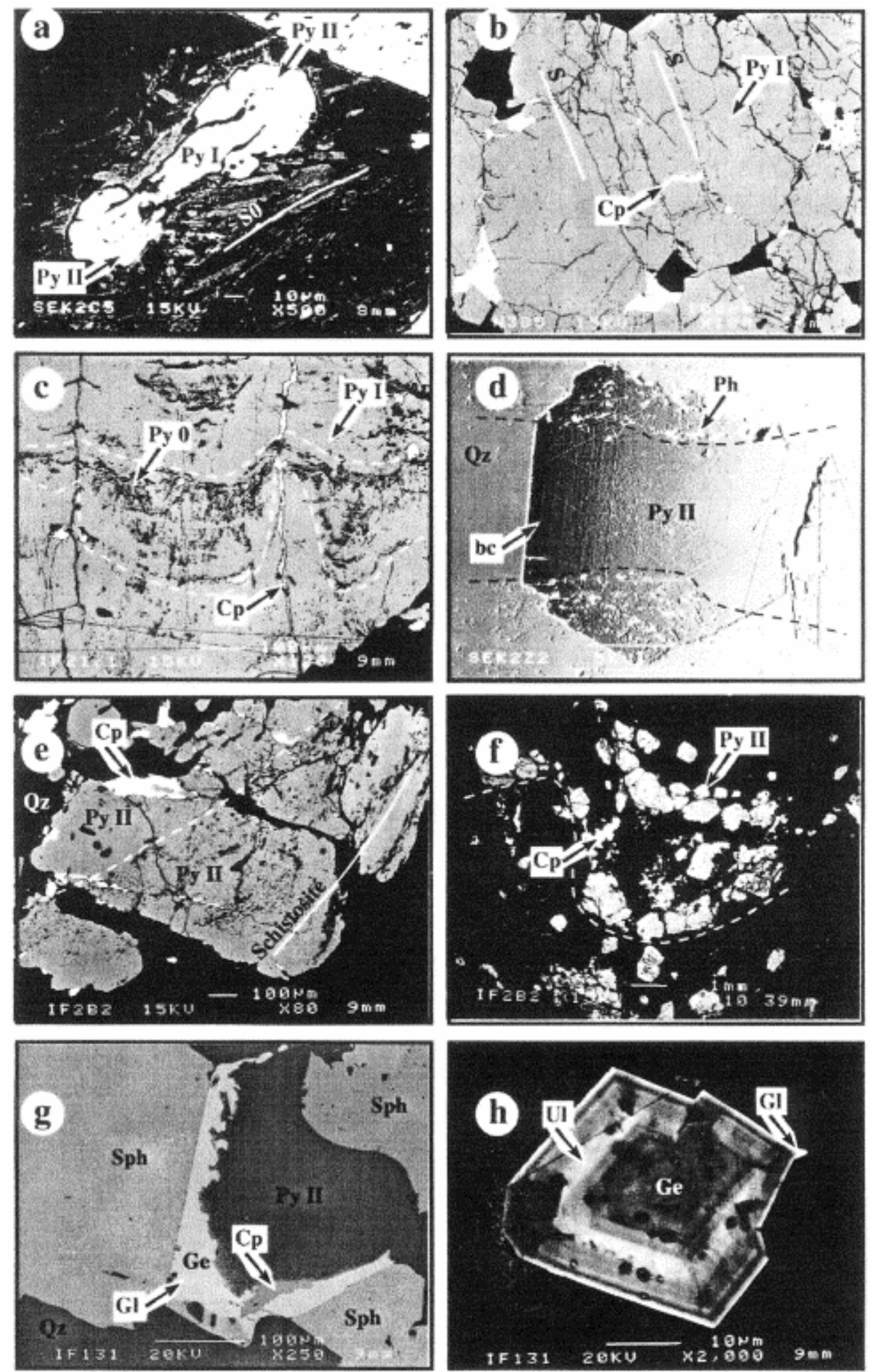

Fig. 2. Quelques textures des minéralisations d'Ifri. (a) Minéralisation pyriteuse disséminée (= Py I) avec surcroissance post-cinématique de deux plages de pyrite automorphes (= Py II), S0: stratification; (b) aspect de la minéralisation pyriteuse massive (= Py I), S: fracturation fruste dans la pyrite massive, la chalcopyrite (= Cp) apparaît dans des microfissures sécantes sur la pyrite I; (c) relique de «melnikovite» (= Py 0) dans la minéralisation pyriteuse massive, les courbes en pointillé soulignent les contours des reliques à texture collomorphe, C: fissure à remplissage de chalcopyrite; (d) pyrite II fissurale (= Py II) avec des inclusions phylliteuses déformées $(=\mathrm{Ph})$ recoupées par les bandes de croissance du sulfure (= bc), les limites de la fissure sont marquées par les courbes pointillées, le reste du remplissage fissural est assuré par du quartz $(=\mathrm{Qz})$; (e) fissures plissées à remplissage de pyrite II (= Py II), la courbe en pointillé souligne les microplis, la 
chalcopyrite (= Cp) apparaît dans des fissures sécantes sur la pyrite II (cf. Fig. 2f); (f) pyrite II fissurale (détail de la photo (e)), la puissance de la fissure est plus importante qu'en (d), l'éponte de la fissure (courbe pointillée blanche) correspond à la limite entre pyrite à inclusions de phyllites déformées et pyrite sans inclusions phylliteuses, la chalcopyrite (= Cp) remplie des fissures sécantes sur les pyrites II, Qz = quartz, la courbe continue blanche souligne la schistosité; (g) un aspect du stockwerk cuprifère: association pyrite II (= Py II), chalcopyrite (= Cp), gersdorffite $(=\mathrm{Ge})$, galène $(=\mathrm{Gl})$, sphalérite $(=\mathrm{Sph})$, quartz $(=\mathrm{Qz})$; $(\mathbf{h})$ cristal automorphe de gersdorffite (= zones sombres, Ge) et d'ullmannite (= zones claires, Ul), Gl = galène. (a), (b), (c), (e), (f), (g), (h): images en mode électrons rétrodiffusés ; (d) image en mode électrons rétrodiffusés en contraste de topographie. (a)-(d) échantillons attaqués à l'acide nitrique.Some textures of the Ifri ore. (a) Disseminated pyritic mineralization (= Py I) with post-kinematic overgrowth of two euhedral crystals of pyrite II (= Py II), S0 : stratification ; (b) aspect of the massive pyritic mineralization (= Py I) ; S : rough cleavage in massive pyrite, chalcopyrite (= Cp) fills veinlets postdating pyrite I ; (c) relict of 'melnicovite' (= Py 0$)$ in the massive pyritic mineralization, doted lines outline the collomorphic texture, Cp : chalcopyrite filling veinlet ; (d) veinlet of pyrite II (= Py II) and quartz (= Qz), note the folded phyllitic inclusions $(=\mathrm{Ph})$ cut by the growth bands of pyrite (= bc), the borders of the veinlet are outlined by black doted lines ; (e) folded veinlet infilling with pyrite II (= Py II), dotted line outlines microfold, chalcopyrite (= Cp) occurs in fissures cutting across pyrite II (see also Fig. 2f, enlargement of this photo) ; (f) veinlet of pyrite II and quartz (= Qz), enlargement of Fig. 2e, the thickness of the fissure is greater than in (d), the wall of the veinlet (white dotted line) fits with the limit between pyrite with phyllitic inclusions and pyrite free of phyllitic inclusions, chalcopyrite (=Cp) filling fractures in pyrite II, continuous white line : schistosity ; (g) aspect of the Cu-rich stockwork : pyrite II (= Py II), chalcopyrite (= Cp), gersdorffite $(=\mathrm{Ge})$, galena $(=\mathrm{Gl})$, sphalerite $(=\mathrm{Sph})$, quartz $(=\mathrm{Qz})$; (h) euhedral crystal of gersdorffite (= black zones, Ge) and ullmannite (white zones, Ul), Gl : galena. (a), (b), (c), (e), (f), (g), (h) : backscattered electrons images ; (d) backscattered electrons and contrast topography image. (a), (b), (c), (d) : samples etched with nitric acid.

\section{2. 'White dolomite breccia'}

'White dolomite breccia' is a 100-m-sized strata bound lens-shaped breccia body, with fragments of black-shale, carbonate-shale or massive pyrite in a matrix of coarse-grained white dolomite (Fig. 1). The amount of matrix decreases from the core to the boundary of the body, with eventually a gradual transition from the breccia texture to a stockwork of veinlets infills with white dolomite at the edges ( Fig. 1). The white dolomite breccia is located within the lower carbonate-shale unit, at the footwall of the black-shale unit, but white dolomite veinlets crosscut black-shale and grey dolostone units as well.

\subsection{The Cu-stockwork}

At the moment at Ifri, this mineralization is the only one of economic significance. The Custockwork crosscuts grey dolostone, black-shale, the upper part of the lower carbonate-shale and the 'white dolomite breccia'. The number of Cu-veinlets increases dramatically in the latter. In the Cu-stockwork are found: quartz, pyrite II, chalcopyrite, ankerite, siderite, galena, sphalerite, brannerite, pyrrhotite, gersdorffite, ullmanite, arsenopyrite, bismuth, bismuthinite, emplectite and scarce stannite, cassiterite, scheelite, wolframite, electrum, hessite, native silver. The paragenetic succession is given in Fig. 3. 


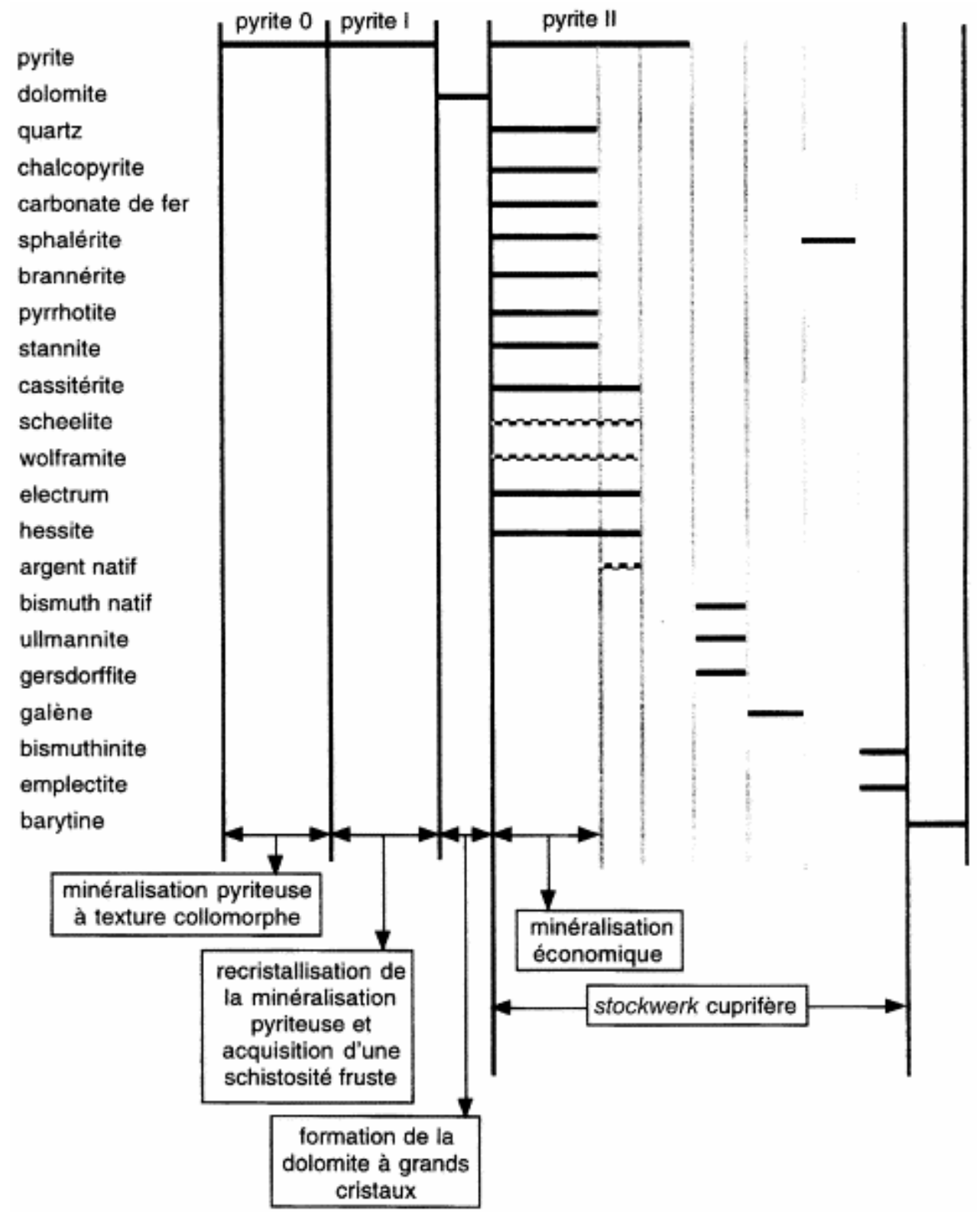

Fig. 3. Succession paragénétique des minéralisations cuprifères d'Ifri.Paragenetic succession of the Cu-bearing mineralization in the Ifri ore deposit.

Pyrite II is found (1) as disseminated grains in black-shale, the upper part of the lower carbonate shale or grey dolostone units; (2) as fissure infilling. Whatever the habitus, pyrite II constantly exhibits the following characteristics: euhedral shape; growth banding (revealed by nitric acid etching); inclusions (sometimes distributed within growth zones) of chalcopyrite, sphalerite and pyrrhotite; other inclusions match with the mineralogy of the host rock (e.g., inclusions of rutile or dolomite in pyrite II, hosted respectively by shale or grey dolostone).

All these features are quite different from those of pyrite I. In disseminated pyrite II, the growth banding overprints metamorphic phyllites. Fissural crystals of pyrite II can grow at the same time in the veinlet and in the hosting rock. In this case, growth zones overprint metamorphic phyllites (Fig. 2d). Within a given crystal, the wall of the veinlet fits with inclusion-free and phyllite-loaded pyrite II ( Fig. 2d and e). At the outcrop scale, these 
veinlets have the appearance of 'beds' of euhedral pyrite ( Fig. 2f), which had been inaccurately interpreted as synsedimentary mineralization [5 and 6].

Chalcopyrite and sphalerite appear first as micro-inclusions in the growth zones of pyrite II, but the main part of chalcopyrite is located within veinlets cutting across pyrite II (Fig. 2e). Textural relations suggest that brannerite and chalcopyrite are contemporaneous. Ni-phases are euhedral ( Fig. $2 \mathrm{~g}$ and h). Occasionally ullmanite and gersdorffite seal the corroded surface of pyrite II. Sn and W minerals occur as micro-inclusions in quartz, pyrite II and chalcopyrite. Phases bearing precious metals are: hessite, native silver and electrum. They generally infill veinlets cutting pyrite II and chalcopyrite.

The formation of the Cu-stockwork is related to an NNW-ward shearing event in the blackshales [2] and can be regarded as the counterpoint in a competent lithology (e.g., grey dolostone and white dolomite breccia) of a ductile deformation in the black shales. Therefore, since the Cu-stockwork and D2 are contemporaneous, the folds outlined by quartz and pyrite II ( Fig. 2d-f) obviously emphasize the simultaneity between shearing and the circulation of the Cu-depositing fluids.

\section{Discussion and conclusion}

The Cu-mineralization is the latest event in a sequence of three: (1) deposition of an early former pyrite mineralization (pyrite 0 ), which suffered the regional deformations (pyrite I); (2) formation of the 'white dolomite breccia'; (3) formation of the Cu-stockwork (pyrite II). The economic mineralization (stage 3) is clearly epigenetic. Structural study [2] shows that the Cu-stockwork formation is linked to the ductile deformation event D2. The lithological control of the Cu-stockwork is linked to the differential competence between coarse-grained white dolomite and black shale or carbonate-shale.

The Cu-stockwork of Ifri displays some similarities with the chalcopyrite ore bodies of Mount Isa [12]. In both cases $\mathrm{Cu}$ ore is spatially associated with epigenetic dolomite and their formation is contemporaneous with a ductile deformation. Regarding the origin of $\mathrm{Cu}$ depositing fluids, presence of scheelite, wolframite, cassiterite and brannerite suggests that a granitic contribution (i.e. Tichka granite) cannot be rejected. Such assumption is supported by a preliminary $\mathrm{Pb} / \mathrm{Pb}$ ionic microprobe dating of brannerite between $264 \pm 67 \mathrm{Ma}$ and $300 \pm 10$ Ma. 


\section{Introduction}

Le district Ba---Cu du Haut Seksaoua est localisé dans le Haut Atlas occidental [3], à la limite

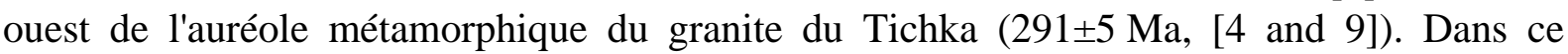
district, le stockwerk cuprifère d'Ifri a jusqu'à présent été considéré comme un amas sulfuré syngénétique [5 and 6] : cette interprétation est basée sur l'existence de rubans de pyrite plissés. Les observations que nous avons réalisées nous ont conduits à reconsidérer l'attribution typologique de cette minéralisation.

\section{Cadre lithostratigraphique et structural du gîte d'Ifri}

La série d'Ifri est composée, de la base vers le sommet, par des « calcschistes inférieurs », des schistes noirs graphiteux, une dolomie grise, des " calcshistes supérieurs ", des gréso-pélites, puis des séricito-schistes. Par comparaison de faciès, un âge Cambrien a été attribué à ces formations [6]. Des faciès volcaniques, présentant une affinité calco-alcaline de marge active, sont intercalés dans la série [10 and 11].

Trois phases majeures de déformation ont été reconnues dans les terrains qui encaissent la minéralisation [2]. La première (D1) est responsable d'une schistosité de flux S1, transposant les plans de la stratification S0. Intervient ensuite un décollement à vergence NNW (D2) auquel sont associés la formation de plis en genoux, puis un serrage est-ouest (D3). Ces trois déformations ont été attribuées à l'orogenèse hercynienne [2]. Par la suite, les terrains d'Ifri ont été le siège de deux phases de fracturation.

\section{Les minéralisations cuprifères d'Ifri}

Deux types de minéralisations sulfurées ont été observées à Ifri : une minéralisation pyriteuse et un stockwerk à chalcopyrite sécant sur la dolomie grise, le schiste noir, la minéralisation pyriteuse et les calcschistes inférieurs. Ce stockwerk est particulièrement dense dans une lentille de brèche à ciment de dolomite blanche à grands cristaux passant latéralement et à son mur aux calcschistes inférieurs et à son toit aux schistes noirs (Fig. 1). Parce qu'elle constitue l'encaissant privilégié du stockwerk cuprifère, cette formation sera décrite en détail par la suite.

\subsection{Minéralisation pyriteuse}

La minéralisation pyriteuse présente deux aspects : disséminée (Fig. 2a) dans les schistes noirs et dans les calcschistes inférieurs, ou massive, en rubans, au toit ou au mur des schistes noirs. Sous la forme disséminée, la pyrite se présente en plages allongées selon la stratification ou en cristaux subautomorphes ourlés d'ombres de pression. Sous la forme massive, la minéralisation pyriteuse apparaît comme un agrégat de cristaux de pyrite (Py I), dont l'assemblage évoque parfois une texture de recuit. On y observe une fracturation fruste (Fig. 2b), semblable à celle quelquefois observée dans les VMS [1]. Parfois les contacts entre cristaux de pyrite sont soulignés par une microbrèche. Au sein de la minéralisation pyriteuse massive, on voit parfois des bandes, conformes à la stratification, composées de pyrite à texture collomorphe (Fig. 2c). Le passage de ces bandes à la minéralisation à texture de recuit est marqué par une disparition progressive de la structure de type " melnikovite ». Enfin, dans le faciès disséminé comme dans le massif, l'attaque à l'acide nitrique ne révèle aucune structure à l'intérieur des grains pyriteux. 
Les textures mises en évidence dans la minéralisation pyriteuse sont caractéristiques des minerais pyriteux métamorphisés (e.g. [1, 7 and 8]), les bandes pyriteuses à texture collomorphe correspondant à des reliques d'une minéralisation initiale (Py 0). La chalcopyrite n'a que très rarement été observée dans ce type de minéralisation.

\subsection{Amas bréchique à ciment de dolomite blanche à grands cristaux}

À l'échelle de la mine, la dolomie blanche à grands cristaux se présente sous la forme d'une lentille stratoïde, constituée d'une brèche à éléments anguleux de schiste noir, de calcschiste ou de minéralisation pyriteuse, cimentés par de grands cristaux de dolomite (Fig. 1). Du coeur de la lentille jusqu'à sa bordure, la proportion de ciment diminue de façon continue. Cette variation induit une modification graduelle de la texture : bréchique au centre de la lentille, la texture devient fissurale à sa périphérie. Situé pour l'essentiel dans les calcschistes inférieurs, au mur des schistes noirs, l'enveloppe de la lentille de brèche à ciment de dolomite blanche peut monter dans la série jusqu'à la dolomie grise incluse.

\subsection{Stockwerk cuprifère}

Ce type de minéralisation constitue à l'heure actuelle la concentration économique. La minéralisation cuprifère est constituée par un stockwerk, qui a été reconnu dans la tranche lithologique allant de la dolomie grise aux calcschistes inférieurs. La puissance des veinules varie de quelques millimètres à $20 \mathrm{~cm}$. Localement, la coalescence des fissures produit des amas à texture bréchique, formés d'éléments d'encaissant cimentés par du quartz et de la chalcopyrite. À Ifri, la densité du stockwerk est nettement plus élevée lorsqu'il recoupe la dolomie blanche à gros cristaux. La minéralisation cuprifère est composée, par ordre décroisant d'abondance, de quartz, de pyrite, de chalcopyrite, d'ankérite, de sidérite, de galène, de sphalérite, de gersdorffite, d'ullmannite, de brannérite, de pyrrhotite, de bismuth natif, de bismuthinite, d'emplectite avec des traces de stannite, de scheelite, de wolframite, de cassitérite, d'électrum, d'argent natif et de hessite.

Le détail de la séquence paragénétique est donné sur la Fig. 3. Dans les grandes lignes, elle débute par le dépôt de pyrite (pyrite II), suivi par une série de phases de fracturation au cours desquelles se mettent en place d'abord la chalcopyrite, puis les minéraux à $\mathrm{Bi}$ et $\mathrm{Ni}$. La pyrite II jouant un rôle clé dans l'interprétation que nous proposons, la description de la microtexture de ce sulfure fera l'objet du prochain paragraphe.

\subsubsection{La pyrite II}

La pyrite II présente deux habitus : soit disséminée au sein du schiste noir, des calcschistes inférieurs et de la dolomie grise, soit en bordure de fissures. Quel que soit son habitus, la pyrite II présente un ensemble de caractéristiques microtexturales, qui permettent de la distinguer aisément des sulfures composant la minéralisation pyriteuse précoce (pyrites 0 et I) : elle est généralement automorphe ; l'attaque à l'acide nitrique révèle des bandes de croissance ; elle contient des inclusions de chalcopyrite, de sphalérite et, plus rarement, de pyrrhotite, parfois disposées selon certaines bandes de croissance ; elle recèle également des inclusions reflétant la nature lithologique de la roche hôte (rutile et phyllites quand l'encaissant est schisteux, dolomite quand l'encaissant est la dolomie grise). Les bandes de croissance de la pyrite II disséminée sont sécantes sur les phyllites déformées. Lorsque les bords du cristal recoupent un niveau riche en produits titanés, l'enveloppe de la zone à inclusion de rutile dessine, au sein du sulfure, les limites de ce niveau. 
Quand elle est située à l'éponte de fractures, la pyrite II peut se présenter en cristaux se développant à la fois dans l'encaissant schisteux et la fissure. Dans ce cas, les bandes de croissance de ce sulfure recoupent les niveaux phylliteux crénulés (Fig. 2d) et au sein d'un même grain de pyrite, l'éponte est marquée par la limite entre une zone contenant des phyllites déformées et une zone libre d'inclusions phylliteuses (Fig. 2d et e). Dans la fissure elle-même, on trouve des cristaux automorphes de pyrite II et de quartz. Remarquons qu'à l'échelle macroscopique, de telles fissures dessinent des rubans de pyrites automorphes (Fig. 2f), qui ont été souvent confondus avec une minéralisation anté-déformation. Enfin, à degré d'ouverture plus important (quelques centimètres), le remplissage se présente sous forme d'une microbrèche à cocarde d'éléments schisteux cimentés par la pyrite II.

\subsubsection{La chalcopyrite et son cortège minéralogique}

La plus grande partie de la pyrite II se forme au début de la séquence de cristallisation, mais ce minéral apparaît de façon plus discrète jusqu'au dépôt des minéraux de Bi et Ni. L'essentiel de la chalcopyrite remplit des fissures sécantes sur la pyrite II précoce (Fig. 2e). Les relations d'inclusion suggèrent que brannérite et chalcopyrite sont contemporaines. Les phases nickélifères sont automorphes (Fig. 2g et h), cachetant parfois la surface corrodée de pyrite II. Le dépôt de l'ullmanite et de la gersdorffite est suivi de celui de galène, puis de sphalérite. Les phases bismuthifères remplissent des microfissures sécantes sur la chalcopyrite et la pyrite II. Les minéraux à Sn-W ont été observés en micro-inclusions dans le quartz, la pyrite II ou la chalcopyrite ou en remplissage de microfissures sécantes sur la pyrite II et la chalcopyrite. L'argent est exprimé sous forme de hessite et sous forme native. L'or apparaît sous la forme de grains d'électrum en inclusions dans la chalcopyrite ou en microfissures sécantes sur ce sulfure.

\subsection{Processus de formation du stockwerk}

La formation du stockwerk cuprifère a été interprétée [2] comme le résultat de l'accommodation d'une déformation présentant un caractère ductile dans les schistes noirs. En effet, l'orientation globale NE-SW des veines du stockwerk est cohérente avec leur développement, en réponse à un cisaillement à vergence vers le NNW (D2). Dans un tel cadre, les structures plissées soulignées par du quartz et la pyrite II (Fig. 2d-f) sont des preuves de la contemporanéité de l'initiation du cisaillement ductile et de la circulation des fluides cuprifères.

\section{Discussion et conclusion}

La structuration du gîte d'Ifri peut être décrite comme l'enchaînement dans le temps de trois événements : (1) dépôt d'une minéralisation pyriteuse (pyrite 0) en grande partie recristallisée (pyrite I) ; (2) formation d'une lentille stratoïde de dolomie à grands cristaux ; (3) mise en place d'un stockwerk cuprifère (pyrite II). Dans un tel cadre, la minéralisation économique (stade 3) présente un clair caractère épigénétique. D'un point de vue typologique, la minéralisation cuprifère d'Ifri présente quelques similitudes avec les corps à chalcopyrite encaissés dans la silica dolomite de Mount Isa [12]. En particulier, dans les deux cas, les zones riches en cuivre sont géométriquement associées à une dolomite épigénétique et contemporaines d'une déformation souple tardive. 
Comme le montre une datation préliminaire $\mathrm{U} / \mathrm{Pb}$ de la brannérite (réalisée à la microsonde ionique, âge compris entre $264 \pm 67$ et $300 \pm 10 \mathrm{Ma}$ ) la formation du stockwerk cuprifère est contemporaine de la mise en place du granite du Tichka. La présence de graphite dans les schistes noirs laisse entendre qu'ils ont pu jouer un rôle de tampon vis-à-vis des fluides métallifères. Enfin, concernant l'origine de ces fluides, la présence dans le stockwerk cuprifère de trace de scheelite, de wolframite et de cassitérite conduit à ne pas rejeter une contribution du granite du Tichka.

\section{Remerciements}

Cette étude a été menée dans le cadre d'une coopération franco-marocaine (Action intégrée 222F/STU/00), avec l'appui de la Snarema, que nous tenons à remercier, ainsi que tout le personnel de la mine d'Ifri, A. Genty, G. Drouet et E. Deloule.

\section{Bibliographie}

1. J.R. Craig and F.M. Vokes, The metamorphism of pyrite and pyritic ores: an overview. Mineral. Mag. 57 (1993), pp. 3-18.

2. A. Chauvet, L. Barbanson, A. Gaouzi, L. Badra, J.-C. Touray and S. Oukarou, Example of a structurally controlled copper deposit from the Hercynian western High Atlas (Moroco), the Hight Seksaoua mining district. In: D.J. Blundell, F. Neubauer and A. Von Quadt, Editors, The timing and location of major ore deposits in an evolving orogenGeol. Soc. Lond. Spec. Publ. 204 (2002), pp. 247-271.

3. J.-J. Cornée, J. Ferrandini, J. Muller and B. Simon, Le Haut Atlas occidental paléozoïque : un graben Cambrien moyen entre deux décrochements dextres $\mathrm{N}^{\circ} 0^{\circ} \mathrm{E}$ hercyniens (Maroc). $C$. R. Acad. Sci. Paris, Ser. II 305 (1987), pp. 499-503.

4. D. Gasquet, J. Leterrier, Z. Mrini and P. Vidal, Petrogenesis of the Hercynian Tichka plutonic complex (Western High Atlas, Morocco): trace element and Rb---Sr and Sm---Nd isotopic constraints. Earth Planet. Sci. Lett. 108 (1992), pp. 29-44.

5. M. Hmeurras, Étude gitologique des minéralisations sulfurées du Haut Seksaoua, rapport inédit, SEGM n²1206, ministère de l'Énergie et des mines, Rabat, 1995, 36 p

6. M. Hmeurras, A. Azza, S. Rchid, O. Belhaj, M. Fdil, M. Mechiche, Les minéralisations cuprifères et barytiques du Haut Seksaoua, Journées géologiques du Maroc, 26-28 octobre 1994

7. G. Lianxing and K.R. McClay, Pyrite deformation in the stratiform lead-zinc deposits of the Canadian Cordillera. Miner. Deposita 27 (1992), pp. 169-181.

8. K.R. McClay and P.G. Ellis, Deformation and recristallization of pyrite. Mineral. Mag. 47 (1983), pp. 527-538.

9. Z. Mrini, Âge et origine des granitoïdes hercyniens du Maroc : apport de la géochronologie et de la géochimie isotopique ( $\mathrm{Sr}, \mathrm{Nd}, \mathrm{Pb})$, thèse d'État, université de Clermont-Ferrand, 1985 
10. H. Ouazzani, Le paléovolcanisme des secteurs de Guedmioua et du Haut-Seksaoua (massif ancien du Haut Atlas occidental, Maroc) : témoin d'un contexte convergent, thèse d'État, université Moulay-Ismaïl, Mekněs, 2000, 281 p

11. H. Ouazzani, A. Pouclet, L. Badra and A. Prost, Le volcanisme d'arc du massif ancien de l'ouest du Haut Atlas occidental (Maroc), un témoin de la convergence de la branche occidentale de l'océan panafricain. Bull. Soc. géol. France 1725 (2001), pp. 67-82.

12. W.G. Perkins, Mount Isa silica dolomite and copper ore bodies; the result of a syntectonic hydrothermal alteration system. Econ. Geol. 794 (1984), pp. 601-637. 